\title{
Regional Government Law Product from The Rule of Law Perspective
}

\author{
Indriyani ${ }^{1}$, Zudan Arief Fakrulloh ${ }^{2}$ \\ \{indri_infor@gmail.com ${ }^{1}$, cclsis@yahoo.com ${ }^{2}$ \} \\ Universitas Borobudur Jakarta, Indonesia ${ }^{1}$ \\ Regional Government Law Product from The Rule of Law Perspective ${ }^{2}$
}

\begin{abstract}
In the concept of the rule of law, it is idealized that what should be used as a guide in the dynamics of state life is law, not politics or economics. For the reason, the legal system needs to making law and enforcing law, starting with the constitution as the supreme law of the land. The Central Government is the President of the Republics of Indonesia who holds the power of the State Government assisted by the Vice President and the Minister as referred to in the Constitution of the Republic ofIndonesia 1945. Likewise, the laws and regulations issued by the Central government together with the House of Representative are the policy directions that are relegated to Regional Legal Products. The Hierarchy of Regional legal products is stated in Law Number 23 of 2014 concerning Regional Government. The regulations of the regional head, referred to as Perkada, are contained in the governor's regulation and the regent/mayor's regulation.In Law Number 12 of 2011 concerning Formation of Law Jo Law Number 15 of 2019 concerning change Law Number 12 of 2011 concerning Formation of Law.
\end{abstract}

Keywords: Law Product; Local Government; Rule of Law

\section{Introduction}

The State of Indonesia is a state that is run based on law or in other words, the state of Indonesia is a state of law, this is contained in the 1945 Constitution of the Republic of Indonesia Article 1 paragraph (3) which states that "the State of Indonesia is a state of law" so that the Indonesian state does not exercise power in a mere government.[1] In a legal state, all state equipment is only carried out based on laws and regulations that have been established so that there is no abuse of power because all kinds of government actions and state equipment in running the wheels of government must be based on law. Because Indonesia is a state of law, it is necessary to establish regulations that regulate all actions of the government and the people of Indonesia. Regulations that are formed must be based on Pancasila and the 1945 Constitution of the Republic of Indonesia, and are compiled from the central to the regional levels based on their hierarchy. It is based on Article 7 paragraph (1) of the Law of the Republic of Indonesia Number 12 of 2011 concerning the Establishment of Legislation, types, and hierarchy of Legislation consists of:[2]

a. the 1945 Constitution of the Republic of Indonesia;

b. Decree of the People's Consultative Assembly; 


\section{c. Laws/Government Regulations in Lieu of Laws;}

d. Government regulations;

e. Presidential decree;

f. Provincial Regulations;

g. Regency/City Regional Regulations.

Based on Article 7 paragraph (1) of the Law of the Republic of Indonesia Number 12 of 2011 concerning the Establishment of Legislation, provincial regulations, and district statutes are included in the hierarchy of laws and regulations, where provincial regulations and district regulations are formed based on the granting of authority, both by attribution and delegation of higher laws and regulations to local governments to form regulations related to the implementation of higher laws and regulations to be implemented in the regions and formed by regional governments based on regional autonomy for the benefit of their regions.[2] However, with many regional regulations being formed, both provincial regulations and district/mayor regional regulations, as well as regional head regulations that are prepared based on the granting of regional autonomy, causes the occurrence of obesity in the laws and regulations, which is caused by overlapping laws and regulations, regulation of content material, which are repeatedly rewritten in regional regulations, both provincial regulations and regency regional regulations after previously having been regulated in detail in higher laws and regulations, as well as the formation of regional regulations that are not based on the granting of authority but for reasons of regional needs, thereby adding to a long list of regional regulations that are the cause of obesity in Indonesian laws and regulations.

Regional legal products have a strategic function to encourage the creation of regional autonomy. For this reason, it is not an exaggeration to say that every local government administrator is required to understand the orderly regulations. Orderly regulation is the process of making good legal products following laws and regulations and the public interest which consists of elements of orderly authority, orderly procedures, orderly substance, and orderly implementation.

A quality local legal product means that the legal product in terms of material content and the way of preparation following the principles of making regulations can answer the problems that exist in people's lives. Meanwhile, an effective regional legal product is interpreted that the legal product that is made is not just finished when it is stipulated, but the legal product is following the needs, applies effectively or effectively, or is on target or achieved its objectives and at the level of implementation can be beneficial to the community.

The types of regional legal products consist of:

1. Legal products in the form of regulation consist of:

a. Provincial Regulations are statutory regulations established by the Provincial Regional People's Representative Council with the Joint Agreement of the Governor; Regency/City Regional Regulations are statutory regulations established by the Regency/City Regional People's Representative Council with the Joint Approval of the Regent/Mayor;

b. Regional Head Regulations referred to as Perkada, are Governor Regulations and/or Regent/Mayor Regulations.

c. Joint Regulations of Regional Heads, Joint Regulations of Regional Heads, abbreviated as $\mathrm{PB} \mathrm{KDH}$ are regulations stipulated by two or more regional heads, which consist of: Joint Regulations of Governors and Joint Regulations of Regents/Mayors

d. DPRD regulations are regulations set by the leadership of the provincial DPRD and the leadership of the regency/municipal DPRD. 
2. Regional legal products in the form of stipulations with concrete, individual and final characteristics consist of:[3]

a. Decisions of the Regional Head, consisting of: Governor's Decree Regent/Mayor Decree

b. DPRD decision

c. DPRD leadership decision

d. The decision of the Honorary Board of DPRD

The principle of the process of forming regional legal products has various types. This principle is used so that the implementation of legal products implemented can function optimally in supporting the realization of regional autonomy and not causing problems in the future. These principles include:

\section{Basis for the Formation of Legislative Rules}

Following the Article 138 paragraph (1) of Law Number 32 of 2004 concerning Regional Government and Article 6 paragraph (1) of Law Number 12 of 2011 concerning the Establishment of Legislation, including:[2]

a. The Principle of Clarity of Purpose is that every Formation of Legislation must have a clear goal to be achieved.

b. The principle of Institutional or Appropriate Forming Officials is that every type of statutory regulation must be made by a state institution or an authorized official forming statutory regulations. These laws and regulations can be canceled or null and void if they are formed by state institutions or officials who are not authorized.

c. The principle of compatibility between types, hierarchies, and content materials is that in the formation of laws and regulations, it is necessary to pay attention to the appropriate material content according to the type and hierarchy of laws and regulations.

d. The Implementable Principle is that every formation of legislation must take into account the effectiveness of the legislation in society, both philosophically, sociologically, and juridically.

e. The principle of usability and usability is that every statutory regulation is made because it is needed and useful in regulating the life of society, nation, and state.

f. The principle of clarity of formulation is that every statutory regulation must meet the technical requirements for the preparation of laws and regulations, systematics, choice of words or terms, as well as legal language that is clear and easy to understand so as not to cause various kinds of interpretations in its implementation.

g. The principle of openness is that in the formation of laws and regulations starting from planning, drafting, discussing, ratifying or determining, and enacting laws, they are transparent and open. Thus, all levels of society have the widest opportunity to provide input in the formation of legislation.

According to Article 5 of Law Number 12 of 2011 Formation of Legislation, including:[2]

a. The principle of protection is that every material contained in the laws and regulations must function to protect to create public peace.

b. The principle of humanity is that every material contained in the laws and regulations must reflect the protection and respect for human rights and the dignity and worth of every citizen and resident of Indonesia proportionally.

c. The principle of nationality is that every material contained in the laws and regulations must reflect the nature and character of the pluralistic Indonesian nation while maintaining the principles of the Unitary State of the Republic of Indonesia. 
d. The principle of kinship is that every material contained in the laws and regulations must reflect deliberation to reach consensus in every decision making.

e. The principle of the Archipelago is that every material containing laws and regulations always pays attention to the interests of the entire territory of Indonesia, and the content of laws and regulations made in the regions is part of the national legal system based on Pancasila and the 1945 Constitution of the Republic of Indonesia.

f. The principle of Bhinneka Tunggal Ika is that the content of laws and regulations must pay attention to the diversity of the population, religion, ethnicity, and class, special conditions of the region, and culture in the life of society, nation, and state.

g. The principle of justice is that every material contained in laws and regulations must reflect justice proportionally for every citizen.

h. The principle of Equality of Position in Law and Government is that any material in the content of laws and regulations may not contain discriminatory matters based on background, among others, religion, ethnicity, race, class, gender, or social status.

i. The principle of Order and Legal Certainty is that every material contained in laws and regulations must create order in society through guarantees of legal certainty.

j. The principle of Balance, Harmony, and Harmony are that every material contained in laws and regulations must reflect balance, harmony, and harmony between the interests of individuals, society, and the interests of the nation and state.

k. Other principles following the legal field of the relevant laws and regulations, for example, the principles in criminal law, principles in civil law, and general principles of proper governance.

\section{Closing}

Regional law products are one part of a rule of law concept that occupies the last position in the types and hierarchy of laws and regulations in Indonesia and is a mandate from Article 18 paragraph (6) of the 1945 Constitution of the Republic of Indonesia which states that the government regions have the right to stipulate regional regulations and other regulations to carry out autonomy and co-administration tasks. But in practice, the formation of regional legal products are often only based on the interests of certain parties, causing problems such as the proliferation of regional legal products that are not needed and becoming the biggest contributor to the obesity of laws in Indonesia, contrary to higher laws and regulations, contrary to the public interest, causing controversy, inhibiting investment, not regulating regional needs, as well as regulating what has been regulated in the laws and regulations which is then the regional legal product that has been formed by spending a large amount of budget and energy, in the end, must be canceled. It is certainly very detrimental to the state and regional finances in particular.

\section{References}

[1] 1945 Constitution of the Republic of Indonesia.

[2] Law of the Republic of Indonesia Number 12 of 2011 concerning the Establishment of Legislation.

[3] Law of the Republic of Indonesia Number 23 of 2014 concerning Regional Government

[4] Amiruddin dan Zainal Asikin. Pengantar Metode Penelitian Hukum. PT. Rajagrafindo Persada, Jakarta (2012). 
[5] Azhary. Negara Hukum Indonesia. UI-Press, Jakarta, 1995. Azhary, Tahir, Negara Hukum. Bulan Bintang, Jakarta (1992).

[6] Manan, Bagir. Menyongsong Fajar Otonomi Daerah. Pusat Studi Hukum (PSH) Fakultas Hukum UII, Yogyakarta (2001).

[7] Manan, Bagir. Perjalanan Historis Pasal 18 UUD 1945. Unsika, Karawang, (1993).

[8] Ali, Faried, dan Nurlina Muhidin. Hukum Tata Pemerintahan Heteronom dan Otonom. Refika Aditama, Bandung (2012).

[9] Budiardjo, Miriam. Dasar-Dasar Ilmu Politik. Gramedia, Jakarta, (1982).

[10] Ridwan, Hukum Administrasi di Daerah, FH UII Press (2009).

[11] Syafie, Inu Kencana. Sistem Administrasi Negara Republik Indonesia (SANRI). Bumi Aksara, Jakarta, pp. 39 (2009)

[12] Fakrulloh, Zudan Arif. Tertib Regulasi Dalam PembentukanProduk Hukum Daerah. Jurnal Ilmu Hukum, (2018).

[13] Law of the Republic of Indonesia Number 15 of 2019 concerning Amendments to Law of the Republic of Indonesia Number 12 of 2011 concerning the Establishment of Legislation 